\title{
PENGARUH PENERAPAN METODE TEKA TEKI SILANG TERHADAP HASIL BELAJAR PENGUASAAN KOSAKATA MURID KELAS III SDN 151 BUNNE KECAMATAN MARIORIWAWO KABUPATEN SOPPENG
}

\author{
Lilis Sri Wahyuni, Sulfasyah \\ Pendidikan Guru Sekolah Dasar, Fakultas Keguruan dan Ilmu Pendidikan \\ Universitas Muhammadiyah Makassar \\ sulfasyah@yahoo.com
}

\begin{abstract}
ABSTRAK
Penelitian ini bertujuan untuk mengetahui pengaruh penerapan metode teka teki silang terhadap hasil belajar penguasaan kosakata murid kelas III SDN 151 Bunne Kecamatan Marioriwawo Kabupaten Soppeng. Jenis penelitian ini merupakan penelitian kuantitatif model eksperimen menggunakan desain Pre-Eksperimental dengan bentuk One Group Pretest-Posttest Design. Sampel penelitian ini adalah murid kelas III SDN 151 Bunne Kecamatan Marioriwawo Kabupaten Soppeng yang berjumlah 9 murid. Dengan demikian sampel penelitian yaitu murid kelas III SDN 151 Bunne Kecamatan Marioriwawo Kabupaten Soppeng. Instrumen penelitian ini berupa tes. Tes yang dibuat oleh peneliti berupa tes obyektif atau pilihan ganda dengan 4 pilihan jawaban sebanyak 15 nomor, sedangkan data hasil penelitian dianalisis secara deskriptif dan inferensial dengan uji t. Berdasarkan uji hipotesis yang telah dilakukan dapat disimpulkan bahwa penggunaan metode teka teki silang berpengaruh terhadap hasil belajar penguasaan kosakata Bahasa Indonesia siswa kelas III SDN 151 Bunne setelah diperoleh nilai $t_{\text {hitung }}$ sebesar 13,82 Dan $t_{\text {tabel }}=2,093$ Maka diperoleh $\mathrm{t}_{\text {hitung }}>\mathrm{t}_{\text {tabel }}$ atau 13,82 > 2,093, maka disimpulkan $\mathrm{H}_{0}$ ditolak $\mathrm{H}_{1}$ diterima yang berarti bahwa penerapan metode teka teki silang berpengaruh terhadap hasil belajar penguasaan kosakata murid kelas III SDN 151 Bunne Kecamatan Marioriwawo Kabupaten Soppeng.
\end{abstract}

Kata kunci : metode teka teki silang, hasil belajar penguasaan kosakata 


\section{PENDAHULUAN}

Pendidikan bertujuan menumbuh kembangkan potensi manusia agar menjadi manusia yang seutuhnya. Pendidikan akan membawa perubahan sikap, perilaku dan nilai-nilai pada individu, kelompok, dan masyarakat. Sejalan dengan itu Bahasa memungkinkan manusia untuk saling berkomunikasi, saling berbagi pengalaman, saling belajar dari yang lain, dan meningkatkan kemampuan intelektual. Bahasa Indonesia memiliki kedudukan dan fungsi yang sangat penting yakni sebagai Bahasa negara dan Bahasa nasional.

Bahasa merupakan salah satu hasil kebudayaan yang harus dipelajari dan diajarkan. Dengan bahasa, kebudayaan suatu bangsa dapat dibentuk, dibina, dan dikembangkan serta dapat diturunkan kepada generasi-generasi mendatang. Bahasa memungkinkan manusia dapat memikirkan suatu masalah secara teratur, terus-menerus, dan berkelanjutan. Sebaliknya, tanpa bahasa peradaban manusia tidak mungkin dapat berkembang dengan baik. Pengajaran bahasa Indonesia pada hakikatnya merupakan salah satu sarana mengupayakan pembinaana dan pengembangan bahasa indonesia secara terarah. Maka dari itu, melalui proses $\begin{array}{llr}\text { pengajaran } & \text { bahasa } & \text { Indonesia } \\ \text { diharapkan } & \text { murid } & \text { mempunyai }\end{array}$ kemampuan yang memadai untuk dapat menggunakan bahasa Indonesia dengan baik dan teratur.

Salah satu metode yang menarik dari sekian metode adalah metode permainan. Metode permainan merupakan suatu kegiatan yang dimainkan menurut aturan tertentu yang menimbulkan kesenangan, tantangan dan dapat mengembangkan keterampilan. Tujuan metode permainan adalah agar pembelajaran dapat berlangsung sesuai dengan apa yang ingin dicapai dan memberi hasil yang optimal. Permainan dalam pembelajaran tidak membosankan sehingga proses dan hasil belajar dapat meningkat.

Agus Suryana (2009: 2) dalam bukunya Learning English With Crosswords mengatakan bahwa "belajar bahasa bisa menimbulkan rasa bosan jika tidak dilakukan dengan bermain. Salah satunya adalah melalui crosswords atau teka-teki silang". Dengan adanya crosswords pembelajar didorong agar tidak jenuh dalam belajar bahasa, dan terpacu untuk mengingat apa yang telah dipelajari sebelumnya.

Selain menggunakan permainan, media juga sangat penting dalam proses 
pembelajaran. Media adalah seperangkat peralatan pendidikan dan pengajaran yang digunakan untuk membantu penyajian materi pelajaran kepada siswa agar dapat mencapai tujuan yang diharapkan.

Berdasarkan uraian dari awal, dapatlah dikatakan bahwa strategi pembelajaran bahasa khususnya penguasaan kosakata di kelas perlu mendapatkan porsi yang seimbang dalam proses belajar mengajar karena kenyataan didapatkan di lapangan antara tuntutan kurikulum dan pelaksanaan pembelajaran khususnya kosakata di kelas belum tercapai kesesuaiannya. Berdasarkan hasil observasi, proses belajar mengajar di kelas III SDN 151 Bunne Kecamatan Marioriwawo Kabupaten Soppeng, belum sepenuhnya berjalan dengan baik, hal ini dapat dilihat dari nilai ratarata kelas diperoleh pada tahun 20172018 yaitu 60. Yang mana dikategorikan rendah dari nilai KKM yang ditentukan yaitu 6. Karena guru mengajar menggunakan metode ceramah, penulis mencoba menerapkan metode permainan crosswords dalam meningkatkan kemampuan penguasaan kosakata pada pelajaran bahasa Indonesia.

\section{METODE PENELITIAN}

Jenis penelitian ini adalah penelitian kuantitatif, yang melibatkan satu kelas dengan tujuan untuk mengetahui pengaruh penerapan metode teka-teki silang terhadap hasil belajar penguasaan kosakata Bahasa Indonesia murid kelas III SDN 151 Bunne Kecamatan Marioriwawo Kabupaten Soppeng. Desain penelitian ini merupakan penelitian preeksperimental designs jenis One-Group Pretes-Posttest Design. Dalam penelitian ini hasil perlakuan dapat diketahui lebih akurat, karena dapat membandingkan dengan keadaan sebelum diberi perlakuan (treatment).

Populasi dalam penelitian ini adalah seluruh murid kelas III SDN 151 Bunne Kecamatan Marioriwawo Kabupaten Soppeng yang berjumlah 9 orang. Sampel adalah sebagian anggota populasi yang memberikan keterangan atau data yang diperlukan dalam penelitian. Satuan eksperimen dalam penelitian ini terdiri dari 1 kelas, yaitu murid kelas III SDN 151 Bunne Kecamatan Marioriwawo Kabupaten Soppeng yang berjumlah 9 murid. Dengan demikian sampel penelitian yaitu murid kelas III SDN 151 Bunne Kecamatan Marioriwawo Kabupaten Soppeng. 
Instrumen penelitian ini berupa tes. Tes yang dibuat oleh peneliti berupa tes obyektif atau pilihan ganda dengan 4 pilihan jawaban sebanyak 15 nomor.

\section{HASIL DAN PEMBAHASAN}

Berdasarkan hasil penelitian yang dilakukan oleh peneliti di SDN 151 Bunne, maka diperoleh data-data yang dikumpulkan melalui instrument tes sehingga dapat diketahui hasil belajar penguasaan kosa kata Bahasa Indonesia siswa berupa nilai dari kelas III SDN 151 Bunne.

Berikut adalah hasil belajar penguasaan kosakata Bahasa Indonesia siswa kelas III SDN 151 Bunne sebelum diajar dengan menggunakan metode teka-teki silang terdapat pada table di bawah ini.

Table 4.1. Frekuensi dan Persentase Skor Hasil Belajar Penguasaan Kosakata Bahasa Indonesia Kelas III SDN 151 Bunne sebelum diajar menggunakan Metode Tekateki Silang

\begin{tabular}{|c|c|c|c|}
\hline $\begin{array}{c}\text { Tingkat } \\
\text { penguasaan }\end{array}$ & Kategori & Frekuensi & $\begin{array}{r}\text { Persentase } \\
(\%)\end{array}$ \\
\hline $90-100$ & $\begin{array}{c}\text { Sangat } \\
\text { tinggi }\end{array}$ & 0 & 0 \\
\hline $80-89$ & Tinggi & 0 & 0 \\
\hline $70-79$ & Sedang & 1 & 11,11 \\
\hline $60-69$ & Rendah & 0 & 0 \\
\hline
\end{tabular}

\begin{tabular}{|c|c|c|c|}
\hline $\begin{array}{c}\text { Kurang dari } \\
60\end{array}$ & $\begin{array}{c}\text { Sangat } \\
\text { rendah }\end{array}$ & 8 & 88,89 \\
\hline \multicolumn{2}{|c|}{ Jumlah } & 9 & 100 \\
\hline
\end{tabular}

Berdasarkan table 4.1 di atas diperoleh bahwa tingkat penguasaan 90 - 100 dalam kategori sangat tinggi dengan frekuensi 0,80 - 89 dalam kategori tinggi dengan frekuensi 0, 70 79 dalam kategori sedang dengan frekuensi 1 dan persentase 11,11, 60 69 siswa berada dalam kategori rendah dengan frekuensi 0, kurang dari 60 dalam kategori sangat rendah dengan frekuensi 8 dan persentase 88,89. Hal ini menunjukkan bahwa hasil belajar penguasaan kosakata Bahasa Indonesia sebelum diajar dengan menggunakan metode teka-teki silang masuk dalam kategori sangat rendah.

Berdasarkan hasil belajar penguasaan kosakata Bahasa Indonesia siswa kelas III SDN 151 Bunne setelah diajar menggunakan metode teka-teki silang ditunjukkan pada table berikut :

Table 4.2. Frekuensi dan Persentase Skor Hasil Belajar Penguasaan Kosakata Bahasa Indonesia Kelas III SDN 151 Bunne setelah diajar menggunakan Metode Tekateki Silang 


\begin{tabular}{|c|c|c|c|}
\hline $\begin{array}{c}\text { Tingkat } \\
\text { penguasaa } \\
\mathrm{n}\end{array}$ & Kategori & Frekuensi & $\begin{array}{c}\text { Persentas } \\
\text { e (\%) }\end{array}$ \\
\hline $90-100$ & $\begin{array}{c}\text { Sangat } \\
\text { tinggi }\end{array}$ & 1 & 11,11 \\
\hline $80-89$ & Tinggi & 1 & 11,11 \\
\hline $70-79$ & Sedang & 7 & 77,78 \\
\hline $60-69$ & Rendah & 0 & 0 \\
\hline Kurang dari & $\begin{array}{c}\text { Sangat } \\
\text { renda } \\
60\end{array}$ & 0 & 0 \\
\hline \multicolumn{2}{|c|}{ Jumlah } & 9 & 100 \\
\hline
\end{tabular}

Berdasarkan table 4.2 di atas diperoleh bahwa tingkat penguasaan 90 - 100 dalam kategori sangat tinggi dengan frekuensi 1 dan persentase 11,11, 80 - 89 dalam kategori tinggi dengan frekuensi 1 dan persentase 11,11, 70 - 79 dalam kategori sedang dengan frekuensi 7 dan persentase 77,78, 60 - 69 dalam kategori rendah dengan frekuensi 0 , kurang dari 60 dalam kategori sangat rendah dengan frekuensi 0 ,

Berikut adalah nilai rata-rata hasil belajar penguasaan kosakata Bahasa Indonesia siswa kelas III SDN 151 Bunne sebelum diajar dengan menggunakan metode teka-teki silang terdapat pada table di bawah ini.

Tabel 4.3. Deskripsi nilai rata-rata pretest, post-test dan persentase perbandingan nilai rata-rata pre-test dan post-test

\begin{tabular}{|c|c|c|}
\hline NO & Tes & $\begin{array}{c}\text { Hasil } \\
\text { Belajar }\end{array}$ \\
\hline 1. & Pre-test & 43,33 \\
\hline 2. & Post-test & 76,11 \\
\hline \multicolumn{2}{|l|}{ Peningkatan (\%) } & 75,65 \\
\hline
\end{tabular}

Sumber : Data peneliti diolah tahun 2018

Gambaran hasil belajar pada siswa kelas III SDN 151 Bunne sebelum perlakuan ( pre-test ) dapat dilihat pada lampiran, dimana mean ( rata-rata ) skor hasil belajar siswa kelas sebelum menggunakan metode teka-teki silang pada peningkatan penguasaan kosakata Bahasa Indonesia yaitu 43,33 dari skor ideal 100. Dari data tersebut menunjukkan hasil belajar siswa pada tahap pre-test tergolong rendah. Sedangkan mean ( rata-rata ) skor hasil belajar siswa setelah menggunakan metode teka-teki silang yaitu 76,11 Hal tersebut menunjukkan bahwa hasil belajar siswa pada tahap post-test tergolong tinggi.

Selama penelitian berlangsung terjadi perubahan. Perubahan tersebut dapat dilihat pada peningkatan nilai persentase dari nilai rata-rata sebelum perlakuan (pre-test) dan setelah perlakuan ( post-test) yaitu 75,65

Berdasarkan hasil penelitian, pengujian hipotesis menggunakan 
Teknik statistic inferensial yaitu menggunakan uji t yang dapat diketahui bahwa nilai thitung sebesar 13,82 dengan frekuensi ( $d \mathrm{k}$ ) sebesar 9-1 = 8, pada taraf signifikan 0,05 Diperoleh $t_{\text {tabel }}=$ 2,093 Oleh karena $t_{\text {hitung }}>t_{\text {tabel }}$ pada taraf signifikansi 0,05 maka hipotesis nol $\left(\mathrm{H}_{0}\right)$ ditolak dan hipotesis alternative $\left(\mathrm{H}_{\mathrm{a}}\right)$ diterima yang berarti bahwa penggunaan metode teka-teki silang terdapat pengaruh terhadap peningkatan penguasaan kosakata Bahasa Indonesia siswa kelas III SDN 151 Bunne.

Pada bagian ini akan diuraikan hasil yang ditemukan dalam penelitian. Hasil yang dimaksudkan yaitu kesimpulan yang diambil berdasarkan data yang terkumpul dan analisis data yang telah dilakukan.

Pemaparan ini merujuk pada rumusan masalah yang telah dikemukakan pada bab pertama yaitu (1) bagaimana hasil belajar penguasaan kosakata Bahasa Indonesia murid kelas III SDN 151 bunne sebelum diberikan perlakuan, (2) bagaimana hasil belajar penguasaan kosakata Bahasa Indonesia murid kelas III SDN 151 bunne setelah diberikan perlakuan, (3) apakah terdapat pengaruh yang signifikan penggunaan metode teka-teki silang terhadap penguasaan kosakata Bahasa
Indonesia peserta didik kelas III SDN 151 Bunne kecamatan marioriwawo kabupaten soppeng. Untuk membahas masalah tersebut, maka data penelitian ini dianalisis sesuai dengan prosedur yang telah ditentukan pada bab III.

Penelitian ini mengukur pengaruh penggunaan metode pembelajaran yaitu metode teka-teki silang pada hasil belajar penguasaan kosakata Bahasa Indonesia. Penggunaan metode tekateki silang diharapkan mampu membuat siswa lebih termotivasi meningkatkan penguasaan kosakata Bahasa Indonesia. pengaruh metode ini ditinjau dari aspek pengetahuan, keterampilan, dan sikap siswa setelah mengikuti pembelajaran penguasaan kosakata dengan metode tersebut.

Pada bagian ini akan diuraikan hasil yang ditemukan selama melaksanakan penelitian. Hasil dimaksud yaitu kesimpulan yang diambil berdasarkan data yang terkumpul dan analisis data yang telah dilakukan. Sampel dari penelitian ini adalah seluruh siswa kelas III SDN 151 Bunne yaitu 9 orang siswa yang dimana Teknik penentuan sampel dalam penelitian adalah Teknik total sampling.

Berdasarkan data hasil penelitian dalam pelaksanaan tes pilihan ganda penguasaan kosakata sebelum 
menggunakan metode teka-teki silang yang dilakukan peneliti pada siswa kelas III SDN 151 Bunne yaitu nilai tertinggi yang diperoleh siswa adalah 70 yang diperoleh 1 orang, nilai 55 diperoleh 1 orang, 45 diperoleh 1 orang, nilai 40 diperoleh 3 orang, nilai 35 diperoleh 2 0rang, nilai 30 diperoleh 1 orang.

Dari data hasil penelitian yang dilakukan dapat disimpulkan bahwa penguasaan kosakata siswa pada tahap pretest dengan menggunakan instrument test dikategorikan sedang yaitu 11,11\% atau 1 orang dari 9 siswa yang termasuk dalam kategori tuntas, sangat rendah $88,89 \%$ atau 8 dari 9 siswa yang termasuk dalam kategori tidak tuntas. Melihat dari hasil persentase yang ada dapat dikatakan bahwa tingkat penguasaan kosakata Bahasa Indonesia siswa sebelum menggunakan metode teka-teki silang tergolong sangat rendah.

Selain itu, dapat diketahui bahwa nilai dari $\sum f x=295$. Sedangkan nilai dari $\mathrm{N}$ sendiri adalah 9. Oleh karena itu, dapat diperoleh nilai rata-rata (mean) yaitu 32,77 .

Dari hasil analisis data dengan sampel 9 orang yang dianalisis diperoleh gambaran, yaitu tidak ada siswa kelas III SDN 151 Bunne yang mampu memperoleh nilai 100 sebagai skor maksimal. Hal ini dikarenakan kurangnya motivasi dan semangat belajar siswa pada penguasaan kosakata Bahasa Indonesia yang berdampak negatif terhadap nilai akhir yang diperoleh pada tahap pre-test.

Pengaruh metode teka-teki silang dapat terlihat dari hasil kerja siswa yang meningkat setelah diterapkannya metode teka-teki silang pada pembelajaran. Aktivitas yang tinggi akan menciptakan suatu pembelajaran yang yang lebih efektif sehingga hasil tulisan siswa dapat lebih berkualitas. Pemanfaatan metode teka-teki silang dapat dikatakan efektif dalam pembelajaran penguasaan kosakata apabila dapat mengoptimalkan hasil belajar siswa dalam penguasaan kosakata Bahasa Indonesia jika dibandingkan dengan penerapan model ataupun metode pembandingannya yaitu guru hanya menggunakan metode penugasan langsung tanpa disertai pengarahan dan penyampaian tujuan khusus dalam kegiatan pembelajaran. Selain itu, guru belum menerapkan metode pembelajaran yang memfokuskan pada penguasaan kosakata Bahasa Indonesia. Penggunaan metode dalam pembelajaran Bahasa 
Indonesia masih menggunakan metode ceramah yang monoton.

Selama penelitian berlangsung terjadi perubahan terhadap kelas setelah diberikan perlakuan. Perubahan tersebut berupa hasil belajar yang datanya diperoleh setelah diberikan post-test.

Selanjutnya, dari hasil penelitian menunjukkan bahwa hasil belajar Bahasa Indonesia setelah diberikan perlakuan ( post-test ) yakni penggunaan metode teka-teki silang terhadap hasil belajar penguasaan kosakata Bahasa Indonesia dapat dikategorikan sangat tinggi yaitu 11,11\% atau 1 orang dari 9 siswa, tinggi $11,11 \%$ atau 1 orang dari 9 siswa, sedang 77,78\% atau 7 dari 9 siswa, rendah $0 \%$ dan sangat rendah $0 \%$. Sehingga dapat disimpulkan bahwa kemampuan memahami pembelajaran setelah diberikan perlakuan (treatment) yakni penggunaan metode teka-teki silang pada mata pelajaran bahasa Indonesia tergolong tinggi. Jadi dapat disimpulkan bahwa setelah digunakan metode teka-teki silang mempunyai hasil belajar lebih baik dibanding dengan sebelum penggunaan metode teka-teki silang, ini berarti ketuntasan belajar memuaskan secara klasik karena nilai rata-rata yang diperoleh adalah
76,11 dan telah mencapai KKM yang diharapkam yaitu 70. Hal tersebut juga dapat dilihat dari perbandingan hasil persentase nilai rata-rata pre-test dan post-test yaitu 75,65. Dari hasil jumlah perbandingan ( selisih) tersebut sudah jelas bahwa ada peningkatan yang terjadi dari hasil rata-rata pre-test dan post-test. Oleh karena itu, penggunaan metode teka-teki silang pada mata pelajaran Bahasa Indonesia khususnya pada materi penguasaan kosakata, serta dapat digunakan sebagai sumber referensi serta pendukung teori pada penelitian selanjutnya yang akan mengkaji tentang penerapan penggunaan metode teka-teki silang terhadap hasil belajar penguasaan kosakata Bahasa Indonesia.

Dari data hasil analisis dapat disimpulkan bahwa metode teka-teki silang berpengaruh dalam peningkatan penguasaan kosakata Bahasa Indonesia. Meskipun metode teka-teki silang membutuhkan banyak kesabaran dalam pengerjaannya tetapi mampu menggali ide dan menantang siswa untuk mengerjakannya. Untuk itu metode teka-teki silang dapat digunakan guru sebagai metode pembelajaran yang meningkatkan penguasaan kosakata Bahasa Indonesia. Namun guru juga perlu mempersiapkan sebaik mungkin 
agar proses pembelajaran berjalan efektif dan memberikan hasil yang signifikan.

Uji hipotesis digunakan untuk menyimpulkan dan membuktikan kebenaran dari hipotesis yang telah dirumuskan berdasarkan teori yang didukung oleh data yang ada dilapangan. Hipotesis yang diajukan dalam penelitian ini adalah:

HO : jika $t_{\text {hitung }}<t_{\text {tabel }}$ maka penggunaan metode teka-teki silang tidak efektif pada peningkatan hasil belajar penguasaan kosakata Bahasa Indonesia siswa kelas III SDN 151 Bunne kecamatan marioriwawo kabupaten soppeng

Ha : jika $t_{\text {hitung }}>t_{\text {tabel }}$ maka penggunaan metode teka-teki silang efektif pada peningkatan hasil belajar penguasaan kosakata Bahasa Indonesia siswa kelas III SDN 151 Bunne kecamatan marioriwawo kabupaten soppeng

Ketentuan bila $t_{\text {hitung }}<t_{\text {tabel, }}$ maka $\mathrm{H}_{0}$ diterima dan $\mathrm{H}_{\mathrm{a}}$ ditolak. Tetapi sebaliknya apabila $t_{\text {hutung }}>t_{\text {tabel, }}$ maka $\mathrm{H}_{0}$ ditolak dan $\mathrm{H}_{\mathrm{a}}$ diterima.
Pengujian hipotesis menggunakan Teknik statistic inferesial yaitu menggunakan uji t.

Berdasarkan hasil analisis dengan menggunakan rumus uji $t$, dapat diketahui bahwa nilai thitung sebesar 13,82 Dengan frekuensi ( $\mathrm{dk}$ ) sebesar 9$1=8$, pada taraf signifikan 0,05 Diperoleh $t_{\text {tabel }}=2,093$ Oleh karena $t_{\text {hitung }}>t_{\text {tabel }}$ pada taraf signifikansi 0,05 maka hipotesis nol $\left(\mathrm{H}_{0}\right)$ ditolak dan hipotesis alternative $\left(\mathrm{H}_{\mathrm{a}}\right)$ diterima yng berarti bahwa penggunaan metode teka-teki silang terdapat pengaruh terhadap peningkatan penguasaan kosakata Bahasa Indonesia siswa kelas III SDN 151 Bunne.

Hasil analisis di atas yang menunjukkan bahwa terdapat pengaruh terhadap penggunaan metode teka-teki silang yang sejalan dengan hasil observasi yang dilakukan. Berdasarkan data yang diperoleh hasil belajar siswa dalam penguasaan kosakata Bahasa Indonesia masih sangat rendah sebelum diterapkan metode teka-teki silang yaitu berada pada rata-rata 43,33. Sedangkan hasil belajar siswa dalam peningkatan penguasaan kosakata setelah diterapkan metode teka-teki silang berada pada rata-rata 76,11. Ini membuktikan bahwa terdapat perbedaan yang signifikan antara 
sebelum dan sesudah diterapkannya metode teka-teki silang pada siswa.

Berdasarkan hasil analisis yang diperoleh dapat disimpulkan bahwa metode teka-teki silang berpengaruh terhadap peningkatan penguasaan kosakata Bahasa Indonesia siswa kelas III SDN 151 Bunne kecamatan marioriwawo kabupaten soppeng.

\section{KESIMPULAN DAN SARAN}

Simpulan yang lebih rinci berkaitan pelaksanaan pembelajaran dengan menggunakan metode teka teki silang pada peningkatan hasil belajar penguasaan kosakata Bahasa Indonesia siswa kelas III SDN 151 Bunne sebagai berikut :

1. Berdasarkan data yang diperoleh dapat disimpulkan bahwa secara umum penguasaan kosakata Bahasa Indonesia siswa kelas III SDN 151 Bunne sebelum penggunaan metode teka teki silang dikategorikan sangat rendah. Hal ini ditunjukkan dari perolehan persentase hasil belajar siswa yaitu yaitu 11,11\% atau 1 orang dari 9 siswa yang termasuk dalam kategori tuntas, sangat rendah 88,89\% atau 8 dari 9 siswa yang termasuk dalam kategori tidak tuntas sangat rendah.
2. Berdasarkan data yang diperoleh dapat disimpulkan bahwa secara umum hasil belajar siswa kelas III SDN 151 Bunne setelah penggunaan metode teka teki silang berpengaruh terhadap hasil belajar penguasaan kosa kata Bahasa Indonesia siswa kelas III SDN 151 Bunne. Hal ini ditunjukkan dari perolehan persentase hasil belajar siswa yaitu sangat tinggi $11,11 \%$ atau 1 orang dari 9 siswa, tinggi 11,11\% atau 1 orang dari 9 siswa, sedang $77,78 \%$ atau 7 dari 9 siswa.

3. Berdasarkan uji hipotesis yang telah dilakukan dapat disimpulkan bahwa penggunaan metode teka teki silang berpengaruh terhadap hasil belajar penguasaan kosakata Bahasa Indonesia siswa kelas III SDN 151 Bunne setelah diperoleh nilai thitung sebesar 13,82 Dan $t_{\text {tabel }}=2,093$ Maka diperoleh $t_{\text {hitung }}>t_{\text {tabel }}$ atau $13,82>2,093$.

\section{UCAPAN TERIMA KASIH}

Rasa hormat dan Ucapan terima kasih disampaikan kepada SDN 151 Bunne Soppeng atas kerjasamanya melakukan penelitian selama dua bulan ini. Dan terima kasih kepada semua pihak yang telah membantu selama penelitian ini dilakukan. 


\section{DAFTAR PUSTAKA}

Aini, Nur. 2010. Penggunaan Metode Tekateki Silang untuk Meningkatkan Kemampuan Penguasaan Kosakata Murid. Skripsi. Unismuh Makassar.

Akhmad Sudrajat, 2008. Pendekatan, Strategi, Metode, Teknik, Taktik, dan Model Pembelajaran. (online) http://www.psbpsma.org Diakses tanggal 15 Mei 2010.

Ali, Muhammad. 1992. Penelitian Kependidikan Prosedur dan Strategi. Bandung: Angkasa.

Arikunto, Suharsimi. 2002. Dasar Evaluasi Pendidikan. Jakarta: Bumi Aksara.

Departemen Pendidikan Nasional. 1995. Kamus Besar Bahasa Indonesia. Jakarta: Balai Pustaka.

Depdikbud 2003. Kamus Besar Bahasa Indonesia. Jakarta: Balai Pustaka.

Depdiknas. 2003. Undang-Undang Republik Indonesia Nomor 20 Tahun 2003 Tentang Sistem Pendidikan Nasional. Jakarta: CV Eko Jaya.

2004. Kurikulum 2004 Standar Kompetensi SD dan Madrasah Ibtidaiyah. Jakarta: Dharma Bakti.

Hamalik, Oemar. 1989. Media Pendidikan. Bandung: Citra Aditya Bhakti.

Hidayati, Nia. 2009. Manfaat Tekateki Silang. (online) http://niahidayati.net/ Diakses tanggal 18 September 2011.
Hudoyo. 1990. Metodologi Penelitian Pendidikan. Jakarta: Rineka Cipta.

Irmayanti. 2009. Pemanfaatan Media TTS dalam Pembelajaran Sinonim Kata pada Siswa Kelas VIII SMP Negeri 3 Polom Bangkeng Selatan Kabupaten Takalar. Skripsi. Unismuh Makassar.

Kamlia. 2010. Meningkatkan Kemampuan Penguasaan Kosakata Bahasa Indonesia Siswa Kelas V SDN 27 Balombong Kecamatan Ma'rang Kabupaten Pangkep. Skripsi. Unismuh Makassar.

Keraf, Goris. 1991. Diksi dan Gaya Bahasa. Jakarta: Gramedia.

Kridalaksana, Harimurti. 1993. Kamus Linguistik. Jakarta: PT. Gramedia Pustaka Utama.

Rostina. 2010. Kemampuan Menggunakan Kosakata Melalui Media Tekateki Silang Siswa Kelas II SMP Negeri 1 Turatea kabupaten Jeneponto. Skripsi.Unismuh Makassar.

Sadiman, Arif. 1996. Media Pendidikan, Pengertian, Pengembangan, dan Pemanfaatannya. Jakarta: karya Grafindo Persada.

Sanjaya, Wina. 2007. Strategi Pembelajaran. Beriorientasi Standar Proses Pendidikan. Jakarta: Kencana.

Siswojo. 1997. Penelitian Sosial IV. Deparkbud, Direktorat Jenderal Pendidikan Tinggi. Proyek Pengembangan Lembaga Pendidikan Tenaga Kependidikan. Jakarta. 
Soeparno. 1980. Media Pengajaran

Bahasa. Yogya: IKIP Yogya.

Sudjana, Nana. 1987. Dasar-Dasar Proses Belajar Mengajar. Bandung: Rineka Cipta.

2003. Metodologi Penelitian Kompetensi dan Prakteknya. Yogya: Bumi Aksara.

Sugona, Pendi, dkk. 2008. Kamus Besar Bahasa Indonesia. Jakarta: Pusat Bahasa Depdiknas RI.

Surakhmad. 1998. Prestasi Belajar. Bandung: Angkasa.

Suryana, Agus, 2009. Learning English With Crosswords. Jakarta: PT. Prestasi Pustakarya.

Susianti, Evy. 2010. Peningkatan Kemampuan Vocabulery pada Pembelajaran Bahasa Inggris dengan Menggunakan Metode Crosswords Siswa Kelas VII MTS Darus Shafaa Manipi. Makalah. Unismuh Pare-pare.

Sutarjso, Adi dan Ruwin Joko. 1997. Bahasa Indonesia. Ujung Pandang: FKIP Unismuh.

Tarigan, Henry Gutur. 1986. Pengajaran Kosakata. Bandung: Pengajaran Kosakata. Bandung: Angkasa.

Utama, Nababan. 1993. Metodologi Pengajaran Bahasa. Jakarta: Gramedia Pustaka www.Lapaserelle.Com/lm/exerci se/games.page.html diakses Tgl 25 Mei 2010. 